\title{
Pengaruh Motivasi Kerja Terhadap Kinerja Karyawan Pada Yayasan Bait Qur'ani Ciputat
}

\author{
${ }^{1}$ Roni Fadli, ${ }^{2}$ Hasanudin \\ Dosen Fakultas Ekonomi Universitas Pamulang \\ Email : ${ }^{1}$ dosen02328@unpam.ac.id, ${ }^{2}$ dosen02482@unpam.ac.id
}

\begin{abstract}
ABSTRAK
Penelitian ini bertujuan untuk mengetahui pengaruh motivasi kerja terhadap kinerja karyawan pada Yayasan Bait Qur'ani At-Tafkir Ciputat.

Penelitian ini bersifat Asosiatif dengan pendekatan kuantitatif. Sampel yang digunakan dalam penelitian ini sebanyak 50 responden. Teknik analisis data yang digunakan dalam penelitian ini yaitu dengan uji validitas, uji reliabilitas, regresi linier sederhana, koefisien korelasi, koefisien determinasi, dan uji t hitung.

Hasil penelitian ini nilai korelasi sebesar 0,649 yang artinya tingkat hubungan motivasi terhadap kinerja karyawan memiliki tingkat hubungan yang kuat. Nilai Koefisien Determinasi sebesar 0,421 yang artinya variabel motivasi (X) memberikan kontribusi terhadap variabel kinerja karyawan (Y) sebesar 42,1\%, sedangkan sisanya sebesar $57,9 \%$ di pengaruhi oleh variabel lain yang tidak diteliti dalam penelitian ini. Nilai thitung sebesar 5,906 > ttabel 201 dengan Sig 0,000 < 0,05 . artinya terdapat pengaruh yang positif dan signifikan motivasi terhadap kinerja karyawan.
\end{abstract}

\section{Kata Kunci: Motivasi Kerja, Kinerja Karyawan}




\section{PENDAHULUAN}

\section{Latar Belakang Masalah}

Guru merupakan tulang punggung dalam kegiatan pendidikan terutama yang berkaitan dengan kegiatan belajar mengajar. Tanpa peran guru, proses pembelajaran akan terganggu bahkan gagal. Oleh karena itu peran guru dalam upaya menyukseskan pendidikan selalu ditingkatkan dalam pengelolaan pendidikan, dan kinerja atau kinerja guru harus selalu ditingkatkan, mengingat tantangan dunia pendidikan, guna memperoleh sumber daya manusia yang berkualitas yang mampu bersaing di era global. Selain itu, diperlukan pendampingan dan bimbingan pemerintah yang berkelanjutan untuk meningkatkan kualitas guru.

Kinerja dapat diartikan sebagai pencapaian hasil kerja yang sesuai dengan aturan dan standar yang berlaku pada masing-masing organisasi, dalam hal ini sekolah. Kinerja merupakan kebutuhan khusus yang pada akhirnya dapat langsung tercermin dalam keluaran yang dihasilkan, baik dari segi kuantitas maupun kualitas. Kualitas pekerjaan guru akan sangat menentukan kualitas hasil pendidikan, karena guru merupakan pihak yang paling banyak bersentuhan langsung dengan siswa dalam proses pendidikan / pengajaran di lembaga pendidikan / sekolah.

Motivasi menjadi pembaharuan karyawan untuk meningkatkan kinerjanya. Interaksi dalam agensi melibatkan individu dengan perilaku berbeda. Oleh karena itu motivasi ini merupakan subjek yang penting bagi manajer atau kepala sekolah, karena manajer atau manajer harus bekerja dengan dan melalui orang lain. Perbaikan dan pengembangan organisasi juga harus mencakup upaya untuk memahami setiap orang yang berperilaku dengan cara tertentu agar dapat menciptakan kekuatan pendorong karyawan untuk mencapai atau mencapai tujuan kepuasan.

Kemajuan Yayasan Bait Qur'ani AtTafkir Ciputat sangat ditentukan oleh kualitas sumber daya manusia khususnya kinerja. Dalam mengejar tujuan suatu organisasi di sekolah harus didukung oleh kinerja yang baik dari guru di lembaga tersebut, yaitu pekerjaan yang dapat dicapai oleh seseorang atau sekelompok orang dalam suatu organisasi atau lembaga untuk mencapai tujuan organisasi tersebut.

Berdasarkan hasil observasi penulis di Yayasan Bait Qur'ani At-Tafkir Ciputat diketahui bahwa terdapat permasalahan dengan kinerja guru yang rendah misalnya kualitas pekerjaan yang masih rendah akibat guru yang kurang memperhatikan ketepatan waktu dan kebersihan. Persentase tanggung jawab masih rendah, karena ada guru yang tidak mau mengakui pekerjaannya dan kesalahannya saat mengambil keputusan yang tidak tepat. Kerja sama masih rendah, karena masih ada guru yang kesulitan bekerja dengan guru tertentu. Inisiatif yang rendah, hal ini terlihat dari situasi dimana guru tidak memiliki inisiatif pribadi untuk mengerjakan pekerjaan lain di waktu luangnya, namun sebagian guru hanya mengisi waktu kerjanya dengan hal-hal lain di luar pekerjaan, seperti bermain internet dan bermain alat komunikasi.

Yayasan Bait Qur'ani At-Tafkir Ciputat senantiasa berupaya meningkatkan kinerja para pengajarnya guna menciptakan 
sumber daya manusia yang berkualitas dan profesional. Berbagai upaya telah dilakukan untuk meningkatkan kinerja staf, diantaranya dengan pemberian berbagai kegiatan pelatihan untuk meningkatkan kinerja guru. Namun, bukan hanya faktor-faktor tersebut yang memengaruhi kinerja guru.

Faktor lain yang mempengaruhi kinerja guru adalah motivasi. Seorang guru dapat bekerja secara profesional jika dia memiliki motivasi yang tinggi. Guru yang bermotivasi tinggi akan antusias dengan tanggung jawab mereka, karena mereka telah menetapkan tujuan. Motif inilah yang menjadi penggeraknya, sehingga mereka ingin bekerja keras.

"Motivasi adalah keadaan kepribadian seseorang yang mendorong individu untuk melakukan tindakan tertentu untuk mencapai suatu tujuan" (Handoko, 2013: 252). Dengan demikian, motivasi merupakan faktor yang ada pada diri seseorang dan mendorong perilakunya untuk mencapai tujuan tertentu. Dalam praktiknya, karyawan dengan motivasi kerja yang tinggi juga cenderung memiliki kinerja yang baik dan tinggi.

Guru dengan moral yang tinggi akan meningkatkan kinerjanya. Loyalitas dan moralitas terbukti dari fakta bahwa mereka merasa puas dengan pekerjaan mereka. Mereka akan lebih memperhatikan, imajinasi dan keterampilan dalam pekerjaannya. Dengan demikian, guru atau staf membutuhkan motivator yaitu untuk memenuhi kebutuhan fisik dan nonfisik. Dalam memenuhi kebutuhan tersebut, guru atau staf pasti ingin bekerja dan melaksanakan tugasnya dengan baik.
Penelitian yang mendukung pengaruh motivasi terhadap kinerja dilakukan oleh Zubaidah (2016) yang menyatakan bahwa motivasi guru berpengaruh positif dan signifikan terhadap kinerja guru.

\section{TINJAUAN PUSTAKA}

\section{Motivasi Kerja}

Menurut Hasibuan (2016:141), "motivasi adalah mengarahkan daya dan potensi bawahan agar mau bekerjasama secara produktif berhasil mencapai dan mewujudkan tujuan yang telah ditentukan". Menurut Rivai (2015:455), "motivasi kerja adalah serangkaian sikap dan nilainilai yang mempengaruhi individu untuk mencapai hal yang spesifik sesuai dengan tujuan individu". Sedangkan menurut Silalahi (2013:341) "motivasi didefinisikan sebagai dorongan dari dalam diri individu berdasarkan mana dari berperilaku dengan cara tertentu untuk memenuhi keinginan dan kebutuhannya".

Menurut Mashlow yang dikutip oleh Hasibuan (2016:105), dimensi dan indikator untuk memenuhi tingkat motivasi kerja pada pegawai adalah sebagai berikut:

1. Kebutuhan fisik

Berhubungan dengan kebutuhankebutuhan utama, dasar dan esensial yang harus dipenuhi setiap manusia untuk mempertahankan diri sebagai mahkluk, kebutuhan ini mencakup misalnya: udara, makan, minum, pakaian, tempat tinggal atau penginapan, istirahat, pemenuhan seksual.

2. Kebutuhan keamanan

Apabila kebutuhan fisiologikal cukup dipenuhi, maka kebutuhan pada tingkatan berikut yang lebih 
tinggi yakni kebutuhan akan keamanan, mulai mendominasi kebutuhan manusia. Kebutuhan keamanan harus dilihat dalam arti luas, tidak hanya dalam arti keamanan fisik akan tetapi keamanan fisiologi dan perlakuan adil dalam pekerjaan atau jabatan seseorang. Karena pemuasan kebutuhan ini terutama dikaitkan dengan kekayaan seseorang. Kebutuhan keamanan itu berkaitan dengan tugas pekerjaannya.

3. Kebutuhan sosial

Kebutuhan ini merupakan kebutuhan manusia untuk menjadi bagian dari kelompok, mencintai dan dicintai orang lain dan bersahabat. Manusia pada dasarnya selalu ingin hidup berkelompok dan tidak seorangpun manusia ingin hidup menyendiri ditempat terpencil.

4. Kebutuhan penghargaan

Kebutuhan ini berkaitan dengan keinginan manusia, untuk dihormati dan dihargai orang lain sesuai dengan kemampuan yang dimilikinya dan ingin punya status, pengakuan serta penghargaan prestise timbul karena adanya prestasi, tetapi tidak selamanya demikian. Prestasi dan status dimanifestasikan oleh banyak hal yang digunakan sebagai simbol status.

5. Kebutuhan akualisasi diri

Kebutuhan aktualisasi adalah kebutuhan yang menggunakan kecakapan, kemampuan, keterampilan dan potensi optimal untuk mencapai prestasi kerja yang sangat memuaskan yang sulit dicapai orang lain. Faktor-faktor khusus yang harus diperhatikan oleh organisasi mencangkup misalnya: tugas yang menantang, kreatifitas, kemajuan dalam organisasi, prestasi dalam pekerjaan.

\section{Kinerja Karyawan}

Menurut Mangkunegara (2015:67), "kinerja adalah hasil kerja secara kualitas dan kuantitas yang dicapai oleh seorang pegawai dalam melaksanakan tugasnya sesuai dengan tanggung jawab yang diberikan kepadanya". Menurut Edison (2016:190), "Kinerja adalah hasil dari suatu proses yang mengacu dan diukur selama periode waktu tertentu berdasarkan ketentuan atau kesepakatan yang telah ditetapkan sebelumnya". Sedangkan menurut Hasibuan (2016:138), "kinerja karyawan suatu hasil yang dicapai oleh seseorang dalam melaksanakan tugas-tugas yang dibebankan kepadanya".

Adapun indikator kinerja karyawan menurut Mangkunegara (2015:67) adalah sebagai berikut:

1. Kualitas Kerja

Merupakan hasil kerja keras dari para pegawai yang sesuai dengan tujuan yang telah ditetapkan oleh pihak perusahaan sebelumnya. Jika hasil yang dicapai oleh pegawai tersebut tinggi maka kinerja dari pegawai tersebut dianggap baik oleh pihak perusahaan atau sesuai dengan standar yang telah ditetapkan. Ini berarti merupakan suatu tingkatan yang menunjukkan proses pekerjaan atau hasil yang dicapai atas suatu pekerjaan mendekati adanya kesempurnaan.

2. Kuantitas Kerja

Merupakan hasil kerja keras dari pegawai yang bisa mencapai skala maksimal yang telah ditentukan oleh 
pihak perusahaan. Kuantitas kerja menunjukkan jumlah pekerjaan yang dihasilkan individu atau kelompok sebagai persyaratan yang menjadi standar pekerjaan. Setiap pekerjaan memiliki persyaratan yang berbeda sehingga menuntut karyawan harus memenuhi persyaratan tersebut baik pengetahuan, keterampilan, maupun kemampuan yang sesuai.

\section{Tanggung Jawab}

Menunjukan seberapa besar pegawai dalam menerima dan melaksanakan pekerjaannya, mempertanggung jawabkan hasil kerja serta sarana dan prasarana yang digunakan dan perilaku kerjanya setiap hari.

4. Kerjasama

Dengan adanya pegawai yang mempunyai rasa harga diri yang tinggi terhadap pekerjaannya maka pegawai berusaha untuk mencapai hasil terbaik dalam pekerjaan tersebut. Oleh karena itu dengan rasa harga diri yang tinggi terhadap pekerjaannya diharapkan para pegawai dapat meningkatkan kinerja dalam bekerja. Kemampuan bekerja sama yang merupakan suatu tingkatan keadaan dari pegawai dapat menciptakan suasana nyaman dalam bekerja, percaya diri, komunikasi yang baik antar rekan kerja sehingga tercipta peningkatan kinerja.

5. Inisiatif

Inisiatif dari dalam diri anggota perusahaan untuk melakukan pekerjaan serta mengatasi masalah dalam pekerjaan tanpa menunggu perintah dari atasan atau menunjukan tanggung jawab dalam pekerjaan yang sudah menjadi kewajiban pegawai.

\section{METODE PENELITIAN}

\section{Populasi}

Populasi dalam penelitian ini berjumlah 50 responden Yayasan Bait Qur'ani At Tafkir Ciputat.

\section{Sampel}

Teknik pengambilan sampling dalam penelitian ini adalah samplel jenuh, dimana semua anggota populasi dijasikan sebagai sampel. Dengan demikian sampel dalam penelitian ini berjumlah 50 responden.

\section{Jenis Penelitian}

Jenis penelitian yang dipakai adalah asosiatif, dimana tujuannya adalah untuk mengetahui mencari keterhubungan antara.

\section{Metode Analisis Data}

Dalam menganalisis data digunakan uji instrumen, uji asumsi klasik, regresi, koefisien determinasi dan uji hipotesis.

\section{HASIL PENELITIAN}

\section{Analisis Kuesioner}

Tabel 1 Tanggapan Responden Terhadap Motivasi Kerja X

\begin{tabular}{|c|c|c|c|c|c|c|c|c|c|c|}
\hline \multirow{3}{*}{ No } & \multirow{3}{*}{ Pernyataan } & \multicolumn{5}{|c|}{ Jawaban } & \multirow{3}{*}{ 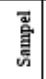 } & \multirow{3}{*}{ క్ } & \multirow{3}{*}{ 焉 } & \multirow{3}{*}{$\overline{\breve{u}}$} \\
\hline & & ss & \begin{tabular}{l|l} 
\\
\end{tabular} & KS & TS & STS & & & & \\
\hline & & 5 & 4 & 3 & 2 & 1 & & & & \\
\hline \multicolumn{11}{|c|}{ Kebutuhan fisik: } \\
\hline 1 & $\begin{array}{l}\text { Gaji yang saya terima cukap untuk } \\
\text { memenuhi kebunuhan sehari-hari }\end{array}$ & 17 & 17 & 7 & 8 & 1 & 50 & 191 & 3,82 & Baik: \\
\hline 2 & $\begin{array}{l}\text { Gaji yang saya terima cukupup untulk } \\
\text { memenuhi kebunuhan tempat tinggal } \\
\text { gaya }\end{array}$ & 17 & 17 & 7 & 8 & 1 & 50 & 191 & 3,82 & Baik \\
\hline \multicolumn{9}{|c|}{ Nilai Rata-rata } & 3,82 & Bailk \\
\hline \multicolumn{11}{|c|}{ Kebutuhan keamanan } \\
\hline 3 & $\begin{array}{l}\text { Saya bekerja mendapat asuransi } \\
\text { kecelakaan }\end{array}$ & 19 & 13 & 9 & 8 & 1 & 50 & 191 & 3,82 & Baik \\
\hline 4 & $\begin{array}{l}\text { Saya bekerja mendapat jaminan } \\
\text { asuransi kesehatan }\end{array}$ & 19 & 17 & 7 & 6 & 1 & 50 & 197 & 3,94 & Baik \\
\hline \multicolumn{9}{|c|}{$\begin{array}{l}\text { Nilai Rata-rata } \\
\end{array}$} & 3,88 & Bailk \\
\hline \multicolumn{11}{|c|}{ Kebutuhan sosial } \\
\hline 5 & $\begin{array}{l}\text { Pimpinan memberikan rekreasi } \\
\text { kepada pegawai pada setiap episode } \\
\text { tertentur agar timbul rasa } \\
\text { kekeluargaan, persahabatan dan kasih } \\
\text { gayang }\end{array}$ & 19 & 17 & 7 & 6 & 1 & 50 & 197 & 3,94 & Baik \\
\hline 6 & $\begin{array}{l}\text { Hubungan antara atasan dan pegawai } \\
\text { selalu terjalin dengan baik }\end{array}$ & 17 & 17 & 8 & 7 & 1 & 50 & 192 & 3,84 & Baik \\
\hline \multicolumn{9}{|c|}{ Nilai Rata-rata } & 3,89 & Bailk \\
\hline \multicolumn{11}{|c|}{ Kebutuhan penghargaan } \\
\hline 7 & $\begin{array}{l}\text { Pimpinan memberikan kedudukan } \\
\text { kepada pegawai yang berpreatasi }\end{array}$ & 16 & 12 & 6 & 5 & 11 & 50 & 167 & 3,34 & $\begin{array}{c}\text { Cukup } \\
\text { Baik }\end{array}$ \\
\hline 8 & $\begin{array}{l}\text { Pimpinan sudah memberikan jabatam } \\
\text { yang sesuai dengan hasil kerja saya. }\end{array}$ & 17 & 17 & 8 & 7 & 1 & 50 & 192 & 3,84 & Baik \\
\hline \multicolumn{9}{|c|}{ Nilai Rata-rata } & 3,59 & Bailk \\
\hline \multicolumn{11}{|c|}{ Kebutuhan alktualisasi diri } \\
\hline 9 & $\begin{array}{l}\text { Perangkat desa diberi kesempatan } \\
\text { unnuk menyampaikaan gagasan atau } \\
\text { ide }\end{array}$ & 17 & 17 & 8 & 6 & 2 & 50 & 191 & 3,82 & Baik \\
\hline 10 & $\begin{array}{l}\text { Perangicat desa mencapai prestasi } \\
\text { kerja atas keahlian yang dimiliki }\end{array}$ & 22 & 14 & 5 & 7 & 2 & 50 & 197 & 3,94 & Baik \\
\hline \multicolumn{9}{|c|}{$\begin{array}{c}\text { Nilai Rata-rata } \\
\end{array}$} & 3,88 & Bailk \\
\hline & EMean Varia & bel M & Lotivas & & & & & & 3,81 & Bailk \\
\hline
\end{tabular}


Berdasarkan pada Tabel 1 tersebut dapat diketahui bahwa secara total 10 pertanyaan yang digunakan untuk mengukur variabel motivasi menghasilkan nilai rata-rata sebesar 3,81 nilai ini bila mengacu pada skala interval masuk pada interval sebesar 3,40 - 4,19. Jadi dapat disimpulkan bahwa motivasi kerja pada Yayasan Bait Qur'ani At Tafkir masuk dalam kategori Baik. Adapun indikator paling tinggi dalam variabel motivasi kerja adalah kebutuhan sosial dengan nilai rata-rata sebesar 3,89 sementara indikator paling rendah adalah indikator kebutuhan penghargaan dengan nilai rata-rata sebesar 3,59.

Tabel 2. Tanggapan Responden Terhadap Kinerja Karyawan Y

\begin{tabular}{|c|c|c|c|c|c|c|c|c|c|c|}
\hline \multirow{3}{*}{ No } & \multirow{3}{*}{ Pernyataan } & \multicolumn{5}{|c|}{ Jawaban } & \multirow{3}{*}{ 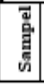 } & \multirow{3}{*}{ ६ू } & \multirow{3}{*}{ క్ํำ } & \multirow{3}{*}{ 苋 } \\
\hline & & SS & \begin{tabular}{l|l} 
\\
\end{tabular} & KS & TS & STS & & & & \\
\hline & & 5 & 4 & 3 & 2 & 1 & & & & \\
\hline \multicolumn{11}{|c|}{ Kuantitas Pekerjaan } \\
\hline 1 & $\begin{array}{l}\text { Saya selah melahukan pekerjan } \\
\text { gevuai target kerja yang ditetagkan } \\
\text { pimpinan }\end{array}$ & 23 & 15 & 6 & 1 & 5 & 50 & 200 & 4,00 & Tinggi \\
\hline 2 & $\begin{array}{l}\text { Saya selahu menyelesaikan pekerijan } \\
\text { melebihi dari target yang ditentukan } \\
\text { pimpinan }\end{array}$ & 30 & 7 & 6 & 2 & 5 & 50 & 205 & 4,10 & Tinggi \\
\hline \multicolumn{9}{|c|}{ Nilai Rata-rata } & 4,05 & Tingi \\
\hline \multicolumn{11}{|c|}{ Kualitas Pekerjaan } \\
\hline 3 & $\begin{array}{l}\text { Saya menyelesaikan pekejazn sesuai } \\
\text { dengan keahlian saya }\end{array}$ & 20 & 18 & 8 & 1 & 3 & 50 & 201 & 4,02 & Tinggi \\
\hline 4 & $\begin{array}{l}\text { Saya cepat tanggap terhadap tugas baru } \\
\text { yang diberikan atasan }\end{array}$ & 31 & 8 & 5 & 3 & 3 & 50 & 211 & 4,22 & $\begin{array}{l}\text { Sangat } \\
\text { Tinggi }\end{array}$ \\
\hline \multicolumn{9}{|c|}{ Nilai Rata-rata } & 4,12 & Tingi \\
\hline \multicolumn{11}{|c|}{ Tanggung Jawab } \\
\hline 5 & $\begin{array}{l}\text { Saya selalu mengejjakan apapun yang } \\
\text { attasan berikan dan menyelesaikan } \\
\text { dengan baik }\end{array}$ & 16 & 12 & 4 & 15 & 3 & 50 & 173 & 3,46 & Tinggi \\
\hline 6 & $\begin{array}{l}\text { Saya mendahulukan pekejjasn- } \\
\text { pekerjagn yang menugakan prioxitas } \\
\text { kerja }\end{array}$ & 25 & 13 & 6 & 3 & 3 & 50 & 204 & 4,08 & Tinggi \\
\hline \multicolumn{9}{|c|}{ Nilai Rata-rata } & 3,77 & Tingi \\
\hline \multicolumn{11}{|c|}{ Kerjasama } \\
\hline 7 & $\begin{array}{l}\text { Saya mamiliki hubungan kejja sama } \\
\text { yang baik dengan rekan kerja saya }\end{array}$ & 26 & 11 & 8 & 2 & 3 & 50 & 205 & 4,10 & Tinggi \\
\hline 8 & $\begin{array}{l}\text { Saya dayat membangun hubungan baik } \\
\text { dengan atasan }\end{array}$ & 22 & 17 & 6 & 1 & 4 & 50 & 202 & 4,04 & Tinggi \\
\hline \multicolumn{9}{|c|}{ Nilai Rata-rata Indikator Kehadiran } & 4,07 & Tingi \\
\hline \multicolumn{11}{|c|}{ Inisitaif } \\
\hline 9 & $\begin{array}{l}\text { Saya memiliki inisiatif yang berguma } \\
\text { membartu penyelesaian pekerjan } \\
\text { yang lebilh baik }\end{array}$ & 22 & 18 & 5 & 1 & 4 & 50 & 203 & 4,06 & Tinggi \\
\hline 10 & $\begin{array}{l}\text { Saya berinisiatif membantu pegavai } \\
\text { lainyya apabila sedang memerlukan } \\
\text { bantuan }\end{array}$ & 19 & 20 & 5 & 1 & 5 & 50 & 197 & 3,94 & Tinggi \\
\hline \multicolumn{9}{|c|}{$\begin{array}{ll} & \text { Nilai Rata-rata } \\
\end{array}$} & 4,00 & Tingi \\
\hline & 7 Mean Variabel K & neria & Karri & awan & & & & & 4,00 & Tingi \\
\hline
\end{tabular}

Sumber : Data Primer diolah penulis (2020)

Berdasarkan pada Tabel 2 secara total 10 pertanyaan yang digunakan untuk mengukur variabel kinerja karyawan menghasilkan nilai rata-rata sebesar
4,00 nilai ini bila mengacu pada skala interval masuk pada interval sebesar $3,40-4,19$. Jadi dapat disimpulkan bahwa kinerja karyawan pada Yayasan Bait Qur'ani At Tafkir masuk dalam kategori Tinggi. Adapun indikator paling tinggi dalam variabel kinerja adalah indikator kualitas pekerjaan dengan nilai ratarata sebesar 4,12 sementara indikator paling rendah adalah indikator tanggung jawab dengan nilai rata-rata sebesar 3,77.

\section{Uji Validitas}

Tabel 3. Hasil Uji Validitas

\begin{tabular}{|c|c|c|c|}
\hline Nilai $\mathbf{r}_{\text {hitung }} \mathbf{X}$ & Nilai $\mathbf{r}_{\text {hitung }} \mathbf{Y}$ & Nilai $\mathbf{r}_{\text {tabel }}$ & Keterangan \\
\hline 0,887 & 0,817 & 0,237 & Valid \\
\hline 0,887 & 0,822 & 0,237 & Valid \\
\hline 0,534 & 0,873 & 0,237 & Valid \\
\hline 0,953 & 0,842 & 0,237 & Valid \\
\hline 0,953 & 0,522 & 0,237 & Valid \\
\hline 0,932 & 0,774 & 0,237 & Valid \\
\hline 0,771 & 0,848 & 0,237 & Valid \\
\hline 0,932 & 0,786 & 0,237 & Valid \\
\hline 0,933 & 0,752 & 0,237 & Valid \\
\hline 0,763 & 0,717 & 0,237 & Valid \\
\hline
\end{tabular}

\section{Dari 20 pernyataan}

disebar kepada karyawan terlihat bahwa seluruhnya memiliki angka tinggi dari $r_{\text {tabell }}(0,237)$ dengan semua item pernyataan valid.

\section{Uji Reliabilitas}

Tabel 4. Hasil Uji Reliabilitas

\begin{tabular}{|l|c|c|}
\hline \multicolumn{1}{|c|}{ Variabel } & Cronbach Alpha & Keputusan \\
\hline Motivasi Kerja $(\mathrm{X})$ & 0,955 & Sangat Reliabel \\
\hline Kinerja Karyawan $(\mathrm{Y})$ & 0,924 & Sangat Reliabel \\
\hline
\end{tabular}

Tabel 4 diatas menunjukan kriteria sudah terpenuhi artinya 40 pernyataan yang disebar kepada karyawan adalah reliabel. 


\section{Uji Regresi Linier Sederhana}

Tabel 5. Regresi Linier Sederhana

\begin{tabular}{|l|l|r|r|r|r|c|}
\hline \multirow{2}{*}{\multicolumn{2}{|c|}{ Model }} & \multicolumn{2}{|c|}{$\begin{array}{c}\text { Unstandardized } \\
\text { Coefficients }\end{array}$} & $\begin{array}{c}\text { Standardized } \\
\text { Coefficients }\end{array}$ & \multirow{2}{*}{$\mathrm{t}$} & \multirow{2}{*}{ Sig. } \\
\cline { 3 - 6 } & B & Std. Error & Beta & & \\
\hline \multirow{2}{*}{1} & (Constant) & 16,716 & 4,077 & & 4,100 & 0,000 \\
\cline { 2 - 7 } & Motivasi & 0,611 & 0,104 & 0,649 & 5,906 & 0,000 \\
\hline
\end{tabular}

a. Dependent Variable: Kinerja Karyawan

Sumber: Hasil Olahan Data SPSS 25

\section{$\mathrm{Y}=\mathbf{1 6 , 7 1 6 + 0 , 6 1 1 X}$}

Nilai constant sebesar 16,716 artinya variabel independen tidak mengalami peningkatan sama sekali yang berarti kinerja karyawan tetap 16,716. Motivasi memperoleh nilai regresi 0,611 berarti bahwa pengaruh yang searah yang artinya semakin baik motivasi karyawan maka akan membuat peningkatan kinerja karyawan 0,611 .

\section{Uji Koefisien Korelasi}

Tabel 6. Uji Koefisien Korelasi

\begin{tabular}{|l|l|r|r|}
\hline \multicolumn{2}{|c|}{} & Kinerja Karyawan & Motivasi \\
\hline $\begin{array}{l}\text { Pearson } \\
\text { Correlation }\end{array}$ & Kinerja Karyawan & 1,000 & 0,649 \\
\cline { 2 - 4 } & Motivasi & 0,649 & 1,000 \\
\hline \multirow{2}{*}{$\begin{array}{l}\text { Sig. (1- } \\
\text { tailed) }\end{array}$} & Kinerja Karyawan & & 0,000 \\
\cline { 2 - 4 } N & Motivasi & 0,000 & \\
\cline { 2 - 4 } & Kinerja Karyawan & 50 & 50 \\
\cline { 2 - 4 } & Motivasi & 50 & 50 \\
\hline
\end{tabular}

Sumber: Hasil Olahan Data SPSS 25

Nilai korelasi sebesar 0,649 yang berarti bahwa tingkat hubungan motivasi terhadap kinerja karyawan memiliki tingkat hubungan yang kuat.

\section{Uji Koefisien Determinasi}

Tabel 7. Koefisien Determinasi

\begin{tabular}{|l|c|r|r|c|}
\hline Model & $R$ & R Square & $\begin{array}{c}\text { Adjusted R } \\
\text { Square }\end{array}$ & $\begin{array}{c}\text { Std. Error of the } \\
\text { Estimate }\end{array}$ \\
\hline 1 &, $649^{\mathrm{a}}$ & 0,421 & 0,409 & 7,25717 \\
\hline
\end{tabular}
a. Predictors: (Constant), Motivasi
Sumber: Hasil Olahan Data SPSS 25

Hasil ini menunjukkan kontribusi (dampak) sebesar $42,1 \%$ yang dihasilkan dari variabel bebas terhadap kinerja karyawan, adapun $57,9 \%$ adalah penyebab dari faktor-faktor lain.

\section{Uji Hipotesis}

Tabel 8. Uji Hipotesis

\begin{tabular}{|c|c|c|c|c|c|c|}
\hline \multirow{2}{*}{\multicolumn{2}{|c|}{ Model }} & \multicolumn{2}{|c|}{$\begin{array}{l}\text { Unstandardized } \\
\text { Coefficients }\end{array}$} & \multirow{2}{*}{$\begin{array}{c}\begin{array}{c}\text { Standardized } \\
\text { Coefficients }\end{array} \\
\text { Beta } \\
\end{array}$} & \multirow[t]{2}{*}{$\mathrm{t}$} & \multirow[t]{2}{*}{ Sig. } \\
\hline & & B & Std. Error & & & \\
\hline \multirow[t]{2}{*}{1} & (Constant) & 16,716 & 4,077 & & 4,100 & 0,000 \\
\hline & Motivasi & 0,611 & 0,104 & 0,649 & 5,906 & 0,000 \\
\hline
\end{tabular}

Hasil pengujian regresi pada tabel 8 angka sig $(0,000<$ 0,01) menunjukan diterimanya $\mathrm{Ha}$ dan ditolaknya Ho yang berarti motivasi berpengaruh terhadap kinerja karyawan pada Yayasan Bait Qur'ani At Tafkir.

\section{PEMBAHASAN PENELITIAN}

HASIL

1. Motivasi kerja pada Yayasan Bait Qur'ani At Tafkir masuk dalam kategori baik. Hal ini dapat dibuktikan dari hasil tanggapan responden (kuesioner) sebesar 3,81 , Nilai ini bila mengacu pada skala interval masuk pada interval $3,40-4,19$ yang memiliki interpretasi baik.

2. Kinerja karyawan pada Yayasan Bait Qur'ani At Tafkir masuk masuk dalam kategori Tinggi. Hal ini dapat dibuktikan dari hasil tanggapan responden (kuesioner) sebesar 4,00. Nilai ini bila 
mengacu pada skala interval masuk pada interval $3,40-4,19$ yang memiliki interpretasi tinggi.

3. Terdapat pengaruh yang positif dan signifikan motivasi terhadap kinerja karyawan pada Yayasan Bait Qur'ani At Tafkir masuk. Hal ini dapat dibuktikan dari persamaan regresi linier sederhana $\mathrm{Y}=16,716+0,611 \mathrm{X}$. Artinya nilai (a) atau konstanta sebesar 16,716 nilai ini menunjukan bahwa pada saat Motivasi $(\mathrm{X})$ bernilai nol atau tidak meningkat, maka kinerja karyawan (Y) akan tetap bernilai 16,716. koefisien regresi nilai (b) sebesar 0,611 (positif) yaitu menunjukkan pengaruh yang searah yang artinya setiap kenaikan motivasi sebesar satu satuan maka akan meningkatkan kinerja karyawan sebesar 0,611 satuan. Nilai korelasi sebesar 0,649 yang artinya tingkat hubungan motivasi terhadap kinerja karyawan memiliki tingkat hubungan yang kuat. Nilai Koefisien Determinasi sebesar 0,421 yang artinya variabel motivasi (X) memberikan kontribusi terhadap variabel kinerja karyawan (Y) sebesar $42,1 \%$, sedangkan sisanya sebesar $57,9 \%$ di pengaruhi oleh variabel lain yang tidak diteliti dalam penelitian ini. Nilai $t_{\text {hitung }}$ sebesar $5,906>t_{\text {tabel }} 201$ dengan Sig 0,000 $<0,05$. artinya terdapat pengaruh yang positif dan signifikan motivasi terhadap kinerja karyawan.

\section{KESIMPULAN DAN SARAN}

\section{A. Kesimpulan}

1. Motivasi kerja pada Yayasan Bait Qur'ani At Tafkir masuk dalam kategori baik. Hal ini dapat dibuktikan dari hasil tanggapan responden (kuesioner) sebesar 3,81, Nilai ini bila mengacu pada skala interval masuk pada interval $3,40-4,19$ yang memiliki interpretasi baik.

2. Kinerja karyawan pada Yayasan Bait Qur'ani At Tafkir masuk masuk dalam kategori Tinggi. Hal ini dapat dibuktikan dari hasil tanggapan responden (kuesioner) sebesar 4,00. Nilai ini bila mengacu pada skala interval masuk pada interval $3,40-4,19$ yang memiliki interpretasi tinggi.

3. Terdapat pengaruh yang positif dan signifikan motivasi terhadap kinerja karyawan pada Yayasan Bait Qur'ani At Tafkir masuk. Hal ini dapat dibuktikan dari persamaan regresi linier sederhana $Y=16,716+0,611 X . \quad$ Nilai korelasi sebesar 0,649. Nilai Koefisien Determinasi sebesar 57,9\% dan Nilai thitung $5,906>t_{\text {tabel }} 201$ dengan Sig $0,000<0,05$.

\section{Saran}

1. Berdasarkan hasil kuesioner pada variabel motivasi diketahui bahwa pernyataan yang paling terendah ada pada pernyataan "Pimpinan memberikan kedudukan kepada pegawai yang berprestasi", dengan skor sebesar 3,34. Yayasan Bait Qur'ani At Tafkir sebaiknya lebih memperhatikan terhadap karyawan yang berprestasi 
baik dengan memberikan reward (penghargaan). Hal ini dapat memotivasi karyawan untuk meningkankan kinerjanya agar lebih baik lagi.

2. Berdasarkan hasil kuesioner pada variabel kinerja pegawai diketahui bahwa pernyataan yang paling terendah ada pada pernyataan "Saya selalu mengerjakan apapun yang atasan berikan dan menyelesaikan dengan baik", dengan skor sebesar 3,46. Penulis menyarankan perlu dilakukan pembinaan dan pengawasan yang harus terus menerus dilakukan dan dikembangkan. Pada dasarnya setiap manusia tidak mau diawasi sehingga selalu ada orang yang berbuat sesuka hati. Karena itulah pengawasan sangat penting peranannya untuk menjaga agar setiap pegawai melaksanakan tugas-tugasnya dengan baik. Pelatihan mengenai kedisiplinan juga perlu dilakukan untuk merubah sikap para pegawai.

3. Bagi peneliti selanjutnya diharapkan dapat mempertimbangkan

menambah variabel-variabel lain seperti gaya kepemimpinan, kompensasi, disiplin kerja, lingkungan kerja, reward dan punishment selain variabel motivasi yang diasumsikan atau diperkirakan dapat mempengaruhi kinerja pegawai.

\section{DAFTAR PUSTAKA}

Akbar, I. R. (2020). Pengaruh Kompensasi Dan Etos Kerja Terhadap Komitmen Organisasi Pada Pt. Central Buana Mandiri. Value: Jurnal Manajemen dan

Akuntansi, 15(1), 73-80

Algifari. (2015). "Analisis Regresi untuk Bisnis dan Ekonomi". Yogyakarta: BPFE.

Edi Sutrisno (2016). Manajemen Sumber Daya Manusia. Jakarta: Prenadamedia Group.

Fadli, R. (2019). Pengaruh Kepemimpinan Terhadap Kinerja Karyawan PT. Tunas Perkasa Tekindo. Jurnal Semarak: Jurnal Ilmiah Prodi Manajemen Universitas Pamulang.

Fadli, R. (2020). Pelatihan Manajemen Waktu dalam Mewujudkan Produktivitas Kerja pada Tenaga Kesehatan RSU Bhakti Asih. Jurnal Baktimas.

Gerry Dessler (2016) Human Resources Management, Prenticehall, London: International Inc.

Hasibuan, Malayu S.P. (2016). Manajemen Sumber Daya Manusia. Edisi Revisi. Jakarta: PT Bumi Aksara.

Istijanto (2014) "Riset Sumber Daya Manusia”. Jakarta: PT. Gramedia Pustaka

Mangkunegara, Prabu Anwar. (2016). Evaluasi Kinerja SDM. Cetakan ke tujuh, PT Refika Aditama: Bandung.

Rialmi, Z., \& Morsen, M. (2020). Pengaruh Komunikasi Terhadap Kinerja Karyawan PT 
Utama Metal Abadi. JENIUS, 3(2), 221-227.

Santoso, Singgih (2015). "Menguasai Statistik Multivariat”. Jakarta: PT Elex Media Komputindo.

Sobarna, A., Hambali, S., Sutiswo, S., \& Sunarsi, D. (2020). The influence learning used $\mathrm{ABC}$ run exercise on the sprint capabilities. Jurnal Konseling dan Pendidikan, 8(2), 67-71.

Sudjana (2014) "Metode Statistika”, Bandung: Tarsido.

Sugiyono (2017), "Metode Penelitian Administrasi : dilengkapi dengan Metode $R$ \& D". Bandung: Alfabeta.

Sunarsi, D. (2018). Buku Ajar: Seminar Perencanaan Sumber Daya Manusia. Tangerang Selatan: Asmoro Mediatama
Sunarsi, D. (2018). Pengembangan Sumber Daya Manusia Strategik \& Karakterisrik Sistem Pendukungnya : Sebuah Tinjauan. Jurnal Ilmiah MEA (Manajemen, Ekonomi, \& Akuntansi), 2(3), 178 - 194.

Sunarsi, D. (2019). Seminar Sumber Daya Manusia. Tangerang Selatan: Unpam Press

Sunarsi, D. (2019). The Analysis of The Work Environmental and Organizational Cultural Impact on The Performance and Implication of The Work Satisfaction. Jurnal Ilmiah Ilmu Administrasi Publik, 9(2), 113122. 